\title{
Do biomass burning aerosols intensify drought in equatorial Asia during El Niño?
}

\author{
M. G. Tosca ${ }^{1}$, J. T. Randerson ${ }^{1}$, C. S. Zender ${ }^{1}$, M. G. Flanner ${ }^{2, *}$, and P. J. Rasch ${ }^{3}$ \\ ${ }^{1}$ Department of Earth System Science, University of California, Irvine, CA, USA \\ ${ }^{2}$ National Center for Atmospheric Research, Boulder, CO, USA \\ ${ }^{3}$ Pacific Northwest National Laboratory, Richland, WA, USA \\ *now at: University of Michigan, Ann Arbor, MI, USA
}

Received: 7 August 2009 - Published in Atmos. Chem. Phys. Discuss.: 2 November 2009

Revised: 24 March 2010 - Accepted: 6 April 2010 - Published: 16 April 2010

\begin{abstract}
During El Niño years, fires in tropical forests and peatlands in equatorial Asia create large regional smoke clouds. We characterized the sensitivity of these clouds to regional drought, and we investigated their effects on climate by using an atmospheric general circulation model. Satellite observations during 2000-2006 indicated that El Niño-induced regional drought led to increases in fire emissions and, consequently, increases in aerosol optical depths over Sumatra, Borneo and the surrounding ocean. Next, we used the Community Atmosphere Model (CAM) to investigate how climate responded to this forcing. We conducted two 30 year simulations in which monthly fire emissions were prescribed for either a high (El Niño, 1997) or low (La Niña, 2000) fire year using a satellite-derived time series of fire emissions. Our simulations included the direct and semi-direct effects of aerosols on the radiation budget within the model. We assessed the radiative and climate effects of anthropogenic fire by analyzing the differences between the high and low fire simulations. Fire aerosols reduced net shortwave radiation at the surface during AugustOctober by $19.1 \pm 12.9 \mathrm{~W} \mathrm{~m}^{-2}(10 \%)$ in a region that encompassed most of Sumatra and Borneo $\left(90^{\circ} \mathrm{E}-120^{\circ} \mathrm{E}, 5^{\circ} \mathrm{S}-\right.$ $5^{\circ} \mathrm{N}$ ). The reductions in net shortwave radiation cooled sea surface temperatures (SSTs) and land surface temperatures by $0.5 \pm 0.3$ and $0.4 \pm 0.2^{\circ} \mathrm{C}$ during these months. Tropospheric heating from black carbon (BC) absorption averaged $20.5 \pm 9.3 \mathrm{~W} \mathrm{~m}^{-2}$ and was balanced by a reduction in latent heating. The combination of decreased SSTs and increased atmospheric heating reduced regional precipitation by $0.9 \pm 0.6 \mathrm{~mm} \mathrm{~d}^{-1}(10 \%)$. The vulnerability of ecosystems to fire was enhanced because the decreases in precipitation
\end{abstract}

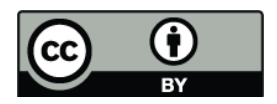

Correspondence to: $\mathrm{M}$. G. Tosca (mtosca@uci.edu) exceeded those for evapotranspiration. Together, the satellite and modeling results imply a possible positive feedback loop in which anthropogenic burning in the region intensifies drought stress during El Niño.

\section{Introduction}

Fire emissions in equatorial Asia vary substantially from year-to-year and generally increase during El Niño (Bowen et al., 2001; Heil and Goldammer, 2001; van der Werf et al., 2006). Emissions from Borneo during the 2006 moderate El Niño, for example, were more than 30 times higher than emissions during the 2000 La Nina (van der Werf et al., 2008). Interactions between anthropogenic and climate factors contribute to this variability. During strong El Niños, both the intensity and spatial extent of regional drought increases (Lyon, 2004). The drought, in turn, lowers the water table and dries fuels. This allows farmers to use fires more effectively as a tool in converting tropical forests and peatlands to croplands and plantations (Page et al., 2002). Page et al. (2002) estimate that between 0.8 and $2.6 \mathrm{PgC}$ was released from peatland fires in Indonesia during the strong 1997-1998 El Niño. More recent estimates of carbon loss are near the lower end of this range (Duncan et al., 2003; van der Werf et al., 2008) but nevertheless support the idea that fires in this region contribute substantially to the global build up of $\mathrm{CO}_{2}$ and $\mathrm{CH}_{4}$ in the atmosphere.

The role of large-scale deforestation as a driver of fire emissions in the region is further illustrated by comparison of visibility records from airports on Sumatra and Borneo (Field et al., 2009). On Sumatra, airport records show a clear relationship between drought and haze events extending back to the beginning of available records in 1960 . On Borneo,

Published by Copernicus Publications on behalf of the European Geosciences Union. 
however, no major haze events occurred prior to 1982, despite a number of significant drought events during the 1960s and 1970s. Field et al. (2009) attribute these differences to changing patterns of migration and land use within the region. Sumatra had relatively high rates of deforestation during the second half of the 20th century, driven in part by surges in population during the 1960s and 1970s. In contrast, Borneo became the target for settlement and development projects by the Indonesian government only later, during the 1980 s and 1990s. Forest clearing and peatland drainage associated with one of these projects, the Mega Rice Project, contributed substantially to the emissions observed during the 1997 El Niño (Page et al., 2002; Field et al., 2009).

Evidence that humans have amplified fire emissions during El Niño in equatorial Asia comes from both the satellite and visibility studies described above. The subsequent impact of these fires on regional and global climate occurs by means of multiple forcing agents (Bowman et al., 2009), including fire effects on greenhouse gas levels (Langenfelds et al., 2002), ozone (Logan et al., 2008), the land surface energy budget (including surface albedo), and aerosols (Duncan et al., 2003; Podgorny et al., 2003). At a regional scale, aerosols are likely to influence climate because aerosol emissions are transported over large areas (Heil et al., 2005; Field et al., 2009) and because their effects on the local radiation budget have been shown to be substantial (Duncan et al., 2003). The response of the climate system to this forcing is not well understood but is important for developing predictive models of future change in the region and for understanding possible feedbacks between climate and fire. In this study, we assessed regional climate impacts of these fires caused by their aerosol emissions by considering their direct radiative effects in a global climate model.

Heil et al. (2005) estimate that the amount of smoke, defined as the sum of black carbon (BC) and organic carbon (OC) aerosol components, released from tropical forest and peatland fires in Indonesia during the 1997 El Niño was $12 \mathrm{Tg} \mathrm{yr}^{-1}$. BC and OC aerosols interact with the radiation budget in different ways, with $\mathrm{BC}$ primarily absorbing shortwave radiation and OC primarily scattering it (Chylek and Coakley, 1974; Haywood and Shine, 1995; Penner et al., 1998). BC absorption of shortwave radiation warms and stabilizes the troposphere (Hansen et al., 1997; Chung et al., 2002) and cools the surface (Ramanathan et al., 2001a; Liepert et al., 2004). OC scattering, in contrast, causes more incoming shortwave radiation to be reflected back into space and as a consequence also contributes to surface cooling. The top of atmosphere (TOA) direct radiative forcing from smoke is unclear, and varies both spatially and temporally as a function of aerosol composition, cloud properties and amounts, and surface albedo. Ackerman et al. (2000) describe semidirect aerosol effects on climate, where shortwave absorption and subsequent atmospheric heating reduces cloud cover that in turn leads to greater energy absorption by the surface and atmosphere.
Fire-emitted aerosols in equatorial Asia have large effects on surface radiation. Podgorny et al. (2003) found that the direct effects of fire aerosols during the fall of 1997 reduced monthly mean net surface insolation by $20-30 \mathrm{~W} \mathrm{~m}^{-2}$ and increased net atmospheric warming by up to $20 \mathrm{~W} \mathrm{~m}^{-2}$ over a region that included much of the tropical Indian Ocean and Indonesia $\left(10^{\circ} \mathrm{S}-10^{\circ} \mathrm{N}, 40^{\circ} \mathrm{E}-160^{\circ} \mathrm{E}\right)$. Similarly, simulations by Duncan et al. (2003) indicate that the fires reduced net surface shortwave radiation by $10 \mathrm{~W} \mathrm{~m}^{-2}$ over the tropical Indian Ocean, with a maximum reduction of $178 \mathrm{~W} \mathrm{~m}^{-2}$ over Indonesia. Despite concurrent atmospheric warming, top of atmosphere radiative forcing was still negative in Duncan et al. (2003), primarily as consequence of scattering by fire-emitted OC aerosols. Together, these two studies provide evidence that reductions in solar radiation from fire-emitted aerosols in Indonesia may be large enough to cause surface cooling and other subsequent changes in the regional climate system.

In tropical regions dominated by oceans, surface cooling and tropospheric heating often increase lower tropospheric stability and reduce convection. Numerous empirical studies link sea surface cooling with increased surface pressure and decreased surface convergence (Graham and Barnett, 1987; Hackert and Hastenrath, 1986). Cooler ocean temperatures decrease surface winds, and the combination reduces convection (Raymond, 1995). Direct tropospheric heating combined with surface cooling from smoke reduces latent heat fluxes and can alter the hydrologic cycle (Rosenfeld, 1999; Liepert et al., 2004; Ramanathan et al., 2001b). Tropospheric heating from BC over the Indian subcontinent also alters the monsoon circulation, with subsequent impacts on precipitation and the hydrologic cycle (Chung and Ramanathan, 2002; Chung et al., 2002). Ackerman et al. (2000) linked reduced subtropical cumulus cloud coverage over the Indian Ocean to BC-induced atmospheric heating. A similar effect was observed in the Amazon where cloud cover decreased by approximately $50 \%$ in response to a fire-induced increase in aerosol optical depth (AOD) of 0.6 averaged over the entire Amazon basin during August-September of 2002 (Koren et al., 2004). Modeling studies by Cook and Highwood (2003) link decreased convective cloud cover to increased stability caused by aerosol absorption. Rosenfeld (1999) observed suppression of tropical convection by optically thick wildfire smoke. Simulations forced with fossil and biofuel-derived brown haze find that absorbing aerosols reduce precipitation by as much as $5 \%$ through a doubling of atmospheric heating (Ramanathan et al., 2005). It is important to note, however, that climate forcing by anthropogenic aerosols may not always reduce precipitation. Both Lau and Kim (2006) and Randles and Ramaswamy (1997) find substantial increases in convection over east Asia resulting from higher tropospheric concentrations of absorbing aerosols. The authors attribute precipitation increases to changes in monsoon circulation and increases in mid-troposphere stability. 
In this study, we examined the climate impact of firederived smoke aerosols in equatorial Asia using satellite data and the Community Atmosphere Model, version 3.1 (CAM3). As a first step, we documented the relation between precipitation, fire emissions and AOD in the region using satellite observations during 2000-2006. We then performed two climate simulations with CAM3, prescribing fire-emitted aerosols for either a high (El Niño) or a low (La Nina) fire year based on a satellite-derived time series of global fire emissions (van der Werf et al., 2006). We found that fires caused a decrease in precipitation that exceeded decreases in evapotranspiration over Sumatra and Borneo. This reduction in water availability, in turn, increased drought stress within the model over source regions, suggesting that a positive feedback loop may exist whereby fires intensify regional drought.

\section{Methods}

To examine the relationship between precipitation, fire emissions and AOD we used several datasets. For precipitation we used the Global Precipitation Climatology Project (GPCP) version 2 monthly dataset with $2.5^{\circ} \times 2.5^{\circ}$ spatial resolution (Adler et al., 2003) and the Tropical Rain Measuring Mission (TRMM 3B43) version 6 monthly dataset with $0.25^{\circ} \times 0.25^{\circ}$ spatial resolution (Kummerow et al., 1998). We obtained AOD data from both the Multi-angle Imaging SpectroRadiometer (MISR) Level 3 daily AOD product (MISR MIL3MAE) and the Moderate Resolution Imaging Spectroradiometer (MODIS) Level 3, Collection 5 monthly AOD product (MOD08 M3). We only used MODIS observations from the Terra satellite because we were interested in extending the time series back to the year 2000 .

For our interpretation of the satellite AOD records described above and for the climate simulations described below, we used fire emissions estimates from GFEDv2 (van der Werf et al., 2006). Burned area in GFEDv2 is estimated using a regression tree approach that relates MODIS active fire observations to MODIS burned area tiles (Giglio et al., 2006). Fuel loads and combustion completeness factors are estimated using a biogeochemical model that is constrained using other satellite data including percent tree cover and the fraction of photosynthetically active radiation absorbed by plant canopies. Aerosol emissions are subsequently obtained from total carbon emissions using emission factors that are separately prescribed for tropical forest, savanna and extratropical forest ecosystems based on a synthesis of available observations by Andreae and Merlet (2001). Emission factors are assigned to each $1^{\circ} \times 1^{\circ}$ grid cell based on the dominant vegetation type in each cell. GFEDv2 CO estimates agree reasonably well with Measurements of Pollution In The Troposphere CO observations over equatorial Asia (van der Werf et al., 2008), providing partial validation of these fluxes for our study region.
We assessed the climate impacts of fire aerosols in equatorial Asia using the Community Atmosphere Model, version 3.1 (CAM3) (Collins et al., 2004) coupled to the SNow ICe And Radiation (SNICAR) model (Flanner et al., 2007). CAM3 was configured with T42 spatial resolution and a slab ocean model with monthly varying surface layer depths and mean ocean heat transport. Prognostic transport and deposition of hydrophobic and hydrophilic BC and OC aerosols followed Rasch et al. (2001). Wet deposition was controlled by below-cloud and in-cloud scavenging. Dry deposition was related to the sum of the aerodynamic resistance, the resistance to transport across the atmospheric sublayer in contact with surface elements, and the surface resistance (Collins et al., 2004). BC optical properties were modified to conform with Bond et al. (2006) as described by Flanner et al. (2007). Hydrophobic BC was assigned a mass absorption cross-section of $7.5 \mathrm{~m}^{2} \mathrm{~g}^{-1}$ (at $550 \mathrm{~nm}$ ) and aged hydrophilic $\mathrm{BC}$ was assumed to have a sulfate coating, which enhanced absorption by a factor of 1.5 . The model parametrizations described above represent the direct effects of aerosols on the radiation budget of the model. A parametrization of indirect aerosol effects on cloud droplet sizes, optical properties and lifetimes was not available within CAM3 at the time of our analysis. These processes are currently under development (Quaas et al., 2009). We plan to repeat these simulations in the future when this improved version of the model becomes available.

We forced CAM3 with monthly emissions of BC and OC from GFEDv2. In one simulation we prescribed GFEDv2 fire emissions from 1997 to represent a high fire (El Niño) year (Fig. 1). In a second simulation, we prescribed fire emissions from 2000 to represent a low fire (La Niña) year. All other aspects of the two simulations were identical, including initial conditions, allowing us to isolate the climate response caused by the fire-induced aerosol forcing. We performed two forty year simulations using these two sets of annually repeating GFEDv2 fluxes. We excluded the first 10 years from each simulation to account for spin-up effects, including adjustments to the hydrologic cycle. In our analysis we defined fire-induced climate anomalies as the difference between the high and low fire simulations.

The slab ocean model responded to the different aerosol loadings in the two simulations, causing changes in SSTs. Large scale ENSO-related conditions and circulations are not represented in the boundary conditions, which are all climatological except for the fire-induced aerosol emissions. Aerosol forcing changed the surface energy budgets of the two simulations but not the prescribed, climatological ocean mixed layer vertical heat fluxes. The resulting SST anomalies dynamically interacted with the atmosphere by means of radiative and turbulent energy fluxes. Thus, the climate responses described here should probably be interpreted primarily as the short-term response (over a time span of several months) of the atmosphere-surface ocean system in equatorial Asia to aerosols from El Niño fires. An important 

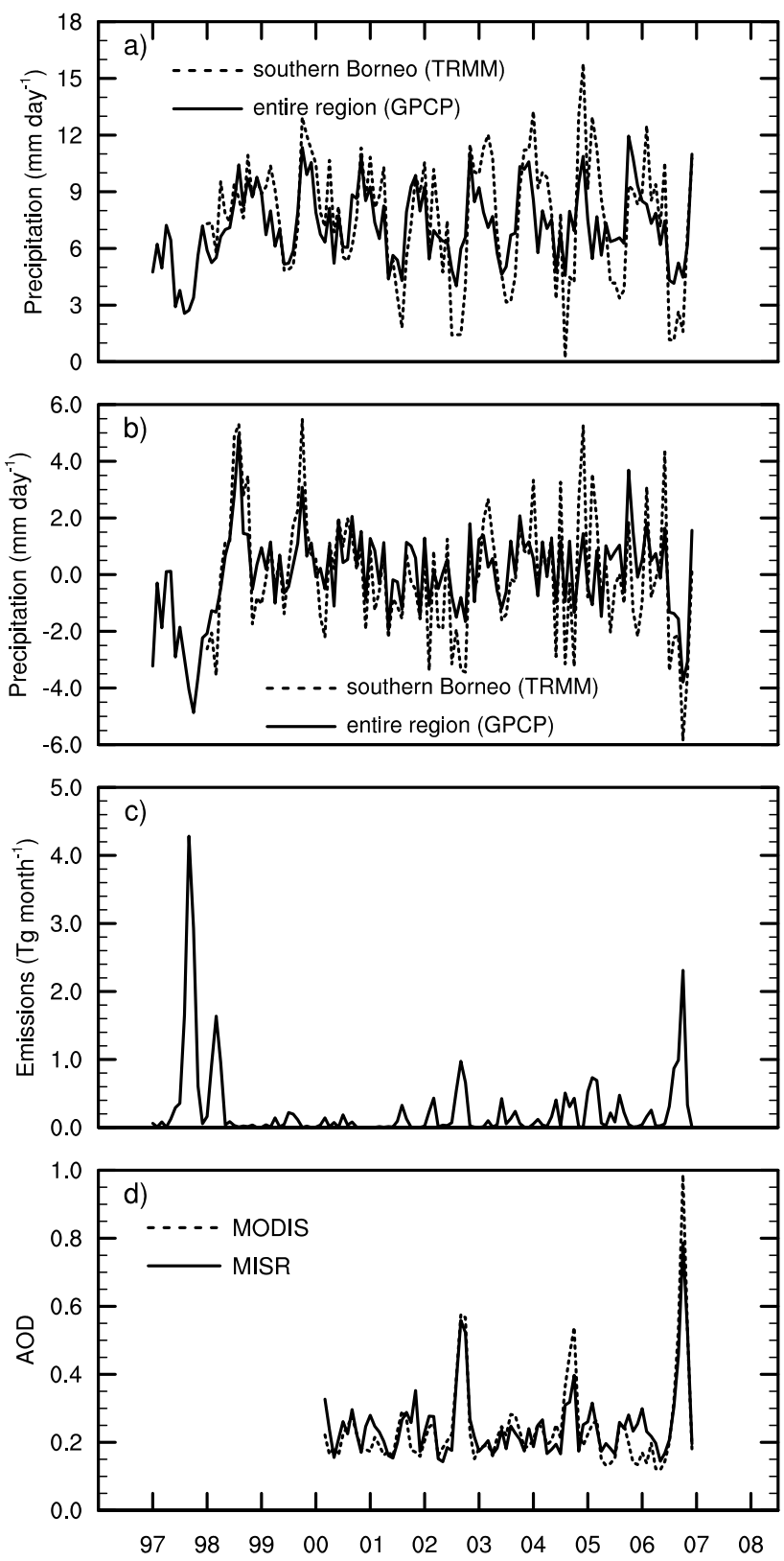

Fig. 1. Satellite-derived observations of precipitation, fire emissions and aerosol optical depth for equatorial Asia $\left(90^{\circ} \mathrm{E}-120^{\circ}\right.$, $5^{\circ} \mathrm{S}-5^{\circ} \mathrm{N}$ ) during $1997-2006$. (a) Monthly mean precipitation totals from GPCP (mm day ${ }^{-1}$ ) for the entire region (solid line) and for southern Borneo from TRMM (south of $1^{\circ} \mathrm{S}$; dashed line). (b) Precipitation anomalies $\left(\mathrm{mm} \mathrm{day}^{-1}\right)-$ similar to (a) but with the annual mean cycle of monthly precipitation removed from both the GPCP and TRMM time series. (c) The sum of BC and OC aerosols from GFEDv2 (Tg month ${ }^{-1}$ ). (d) Aerosol optical depths are from both MISR (solid line) and MODIS (dashed line).

next step (as described below in the discussion) is to repeat this analysis with a prognostic fire emissions model and a fully coupled ocean-atmosphere general circulation model to examine longer term fire-ENSO feedbacks mediated by changes in ocean circulation.

Total carbon emissions in equatorial Asia $\left(90^{\circ} \mathrm{E}-120^{\circ} \mathrm{E}\right.$, $5^{\circ} \mathrm{S}-5^{\circ} \mathrm{N}$ ) were $821 \mathrm{TgC}^{-1}$ in 1997 and $47 \mathrm{Tg} \mathrm{C} \mathrm{yr}^{-1}$ in 2000. During 1997, black carbon (BC) aerosol emissions were $1.2 \mathrm{Tg} \mathrm{yr}^{-1}$ and organic carbon (OC) aerosol emissions were $9.5 \mathrm{Tg} \mathrm{yr}^{-1}$. These emissions corresponded to emissions factors of $0.63 \mathrm{~g} \mathrm{~kg}^{-1}$ for $\mathrm{BC}$ and $5.2 \mathrm{~g} \mathrm{~kg}^{-1}$ for $\mathrm{OC}$ which are almost the same as emission factors reported by Andreae and Merlet (2001) for tropical forests-implying that almost all fire emissions in equatorial Asia from GFEDv2 were from this biome. Monthly GFEDv2 emissions were interpolated to match the time-step resolution of the model and injected into the surface layer (Rasch et al., 2001; Collins et al., 2002).

We injected emissions into the surface layer because many of the fires in this region occur in peatlands (Page et al., 2002) and are thus are expected to have a strong smoldering phase. A preliminary examination of nine years of MISR observations using the MISR INteractive eXplorer (MINX) software (Nelson et al., 2008) confirmed that almost all of the observed fire plumes were injected within the atmospheric boundary layer (ABL) as defined by an interpolation of 6hourly Goddard Earth Observing Model - version 4 (GEOS4) reanalysis estimates.

As a measure of uncertainty, we estimated $95 \%$ confidence intervals for relevant climate variables. To provide regional averages of both climate forcing and response, we estimated mean values for the region bounded by $90^{\circ} \mathrm{E}-120^{\circ} \mathrm{E}$ and $5^{\circ} \mathrm{S}-5^{\circ} \mathrm{N}$. This region included most of Sumatra and Borneo (primary emission source locations) and extended into the eastern Indian Ocean. The land component of this domain is undergoing substantial deforestation (Hansen et al., 2008) and thus is an important area for understanding climate-land use change feedbacks.

\section{Results}

\subsection{Satellite measurements of precipitation, fire emis- sions and AOD in equatorial Asia}

GPCP precipitation had a clear annual cycle and substantial interannual variability within our study region $\left(90^{\circ} \mathrm{E}-\right.$ $\left.120^{\circ} \mathrm{E}, 5^{\circ} \mathrm{S}-5^{\circ} \mathrm{N}\right)$. The mean annual cycle of precipitation had a minimum during August $\left(5.5 \mathrm{~mm} \mathrm{~d}^{-1}\right)$ and a maximum during December (9.4 $\mathrm{mm} \mathrm{d}^{-1}$ ) (Fig. 1a). The strong 1997 El Niño prolonged the dry season and caused a three-month (August-October) negative precipitation anomaly that had a mean of of $-3.9 \mathrm{~mm} \mathrm{~d}^{-1}$ relative to the 1997-2006 period (Fig. 1b). The moderate 2006 El Niño was associated with an August-October precipitation anomaly of $-2.8 \mathrm{~mm} \mathrm{~d}^{-1}$ (Fig. 1b). 

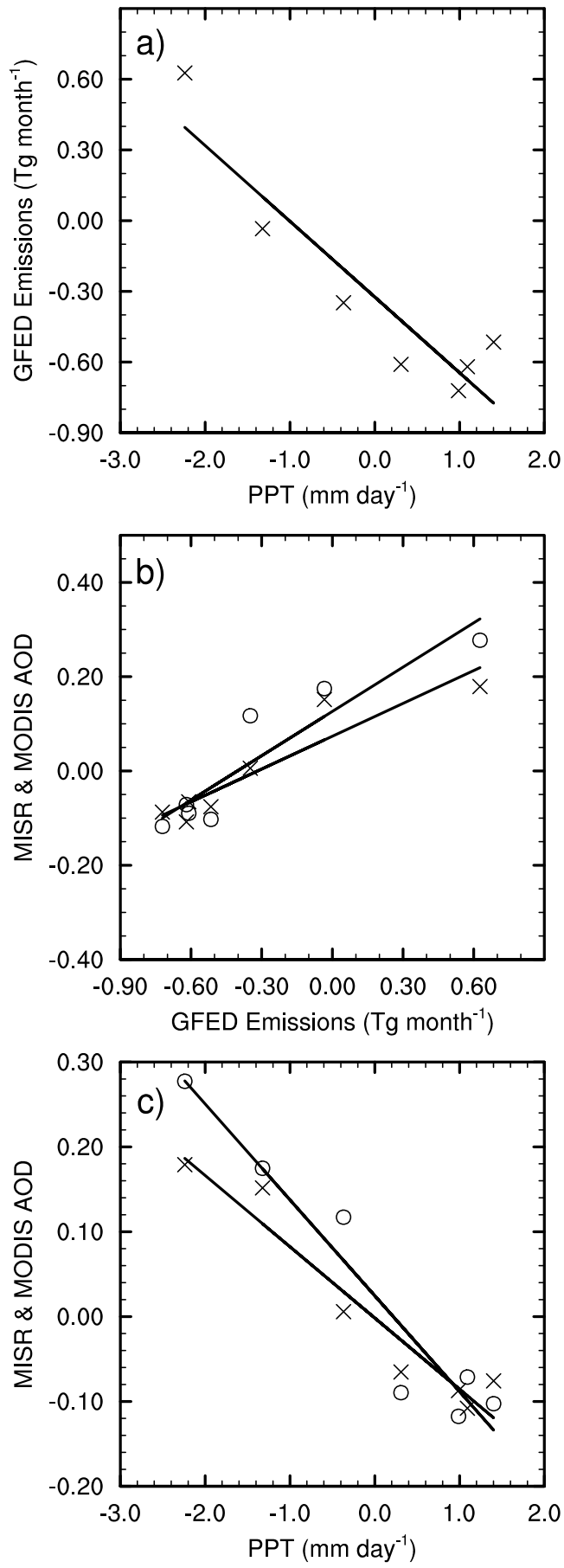

Fig. 2. Causal links between drought and aerosol optical depth in equatorial Asia during 2000-2006. (a) The relationship between GPCP precipitation anomalies and GFED fire emissions anomalies in equatorial Asia $\left(90^{\circ} \mathrm{E}-120^{\circ}, 5^{\circ} \mathrm{S}-5^{\circ} \mathrm{N}\right)$ for the three-month fire season (August-October) during 2000-2006. (b) Same as (a) but for GFEDv2 emissions and either MISR (x) or MODIS (o) AOD anomalies. (c) Same as (b) but for GPCP precipitation anomalies and either MISR (x) and MODIS (o) AOD anomalies. Drought triggers increases in fire emissions that in turn increases aerosol loading in the atmosphere as observed by MISR and MODIS.
The sum of $\mathrm{BC}$ and $\mathrm{OC}$ emissions from GFEDv2 varied considerably from year to year with a maximum in 1997 of $10.7 \mathrm{Tg} \mathrm{yr}^{-1}$ and a minimum of $0.6 \mathrm{Tg} \mathrm{yr}^{-1}$ in 2000 (Fig. 1c). Weak to moderate El Niño years had considerably higher fire emissions than La Ninã or neutral years. For example, mean emissions from 2002, 2004, and 2006 were $3.5 \mathrm{Tg} \mathrm{yr}^{-1}$, nearly a factor of 3 greater than emissions during 2000, 2001 and $2003\left(1.3 \mathrm{Tg} \mathrm{yr}^{-1}\right)$. Maximum combined $\mathrm{BC}$ and $\mathrm{OC}$ emissions (4.3 $\mathrm{Tg}_{\mathrm{month}}{ }^{-1}$ ) occurred in September 1997 when precipitation $\left(2.7 \mathrm{~mm} \mathrm{~d}^{-1}\right)$ was anomalously low $\left(-4.1 \mathrm{~mm} \mathrm{~d}^{-1}\right)$. BC and $\mathrm{OC}$ emissions during the moderate $2006 \mathrm{El}$ Niño were at a maximum during October $\left(2.3 \mathrm{Tg}\right.$ month $\left.^{-1}\right)$ when the precipitation anomaly was $-3.8 \mathrm{~mm} \mathrm{~d}^{-1}$.

The seasonal cycle of MISR and MODIS AOD was characterized by a maximum during late summer and fall and a minimum during winter and spring. AOD maxima were amplified during the El Niños of 2002, 2004 and 2006, with the largest monthly value ( 0.78 for MISR) observed during October of 2006 (Fig. 1d). While GPCP data for the region as a whole did not show anomalously low precipitation levels during 2002 and 2004, monthly-averaged data from TRMM for southern Borneo (south of $1^{\circ} \mathrm{S}$ ), did show substantial drought during the fire season in 2002 and 2004, and an even stronger negative anomaly in 2006. Southern Borneo received 2.9, 2.2 and $3.4 \mathrm{~mm} \mathrm{~d}^{-1}$ less August-October precipitation than normal during 2002, 2004 and 2006, respectively.

Satellite-derived fire emissions during August-October from GFEDv2 were negatively correlated with precipitation anomalies (Fig. $2 \mathrm{a} ; r^{2}=0.85, p \leq 0.01$ ). MODIS and MISR AODs, in turn, were positively correlated with fire emissions (Fig. 2b; MODIS $r^{2}=0.86, p \leq 0.01$, MISR $r^{2}=0.86$, $p \leq 0.01)$. As a consequence, AOD showed a significant, inverse relationship with precipitation in the region (Fig. 2c; MISR $r^{2}=0.93$, MODIS $\left.r^{2}=0.92, p \leq 0.01\right)$. Taken together, these observations indicated that aerosol emissions and optical depths were closely linked with ENSO-induced changes in the hydrological cycle.

\subsection{Climate effects of fire-emitted aerosols as simulated by the Community Atmosphere Model}

The AOD anomaly in CAM3 (the difference between the high fire and low fire simulations) was highest during August, September and October with a maximum value of 0.50 during September (Fig. 3). The high fire simulation produced a spatial pattern of AOD that was similar to observed MISR and MODIS AOD during a moderate El Niño (the mean of 2002, 2004 and 2006) (Fig. 4). Although the magnitude and spatial pattern of the AOD response in CAM (Fig. 4c) was comparable to that observed during a moderate El Niño (Fig. 4a, b), it was considerably lower than expected given that it was derived using fire emissions from 1997 (e.g. Fig. 1). There are several possible causes for this 


\section{a) Sum of BC and OC emissions}

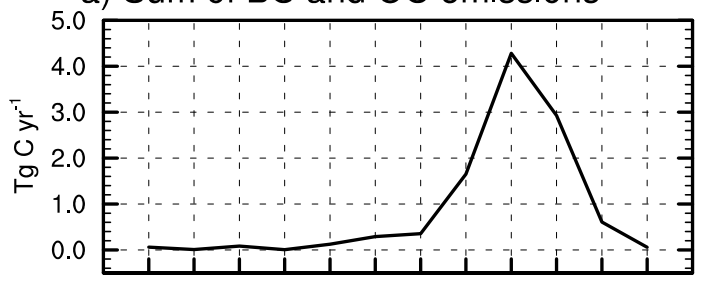

b) Aerosol optical depth

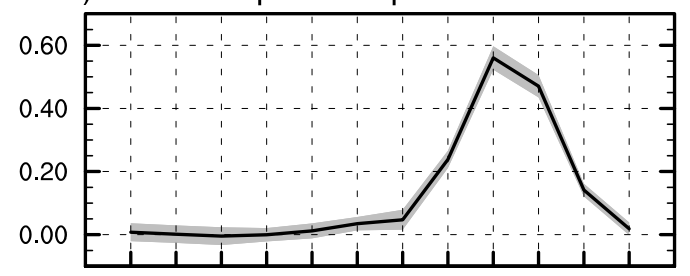

c) All-sky shortwave forcing

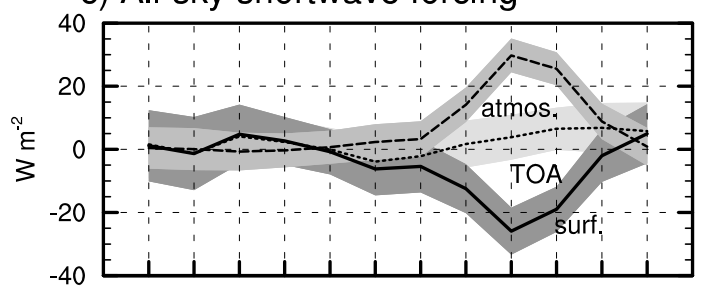

d) Temperature

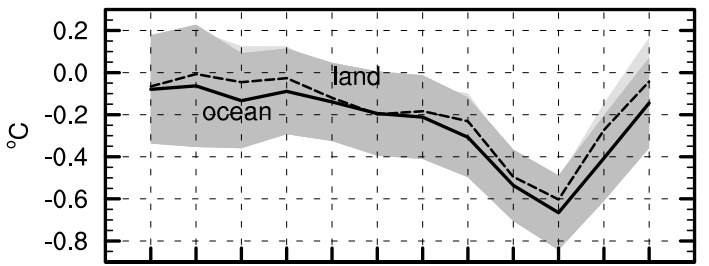

e) Precipitation and evapotranspiration

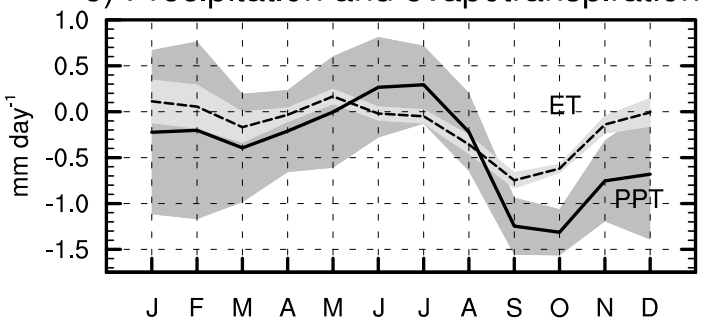

Fig. 3. Climate forcing and response from the two CAM3 simulations described in the text. Each plot shows the annual mean cycle of the difference between the high fire simulation and low fire simulation over the study area $\left(90^{\circ} \mathrm{E}-120^{\circ}, 5^{\circ} \mathrm{S}-5^{\circ} \mathrm{N}\right)$. (a) The GFEDv2 fire emissions used to force the model are in units of $\mathrm{Tg}$ month $^{-1}$. (b) Aerosol optical depths simulated by CAM3 in response to these emissions (unitless). (c) All-sky net shortwave radiation at the surface, for the troposphere, and at the top of the atmosphere (TOA) from the model in units of $\mathrm{W} \mathrm{m}^{-2}$. (d) Sea surface temperatures (solid line) and land surface temperatures (dashed line) in units of ${ }^{\circ} \mathrm{C}$. (e) Precipitation (solid line) and evapotranspiration (dashed line) in units of $\mathrm{mm} \mathrm{d}^{-1}$. Gray error bars denote $95 \%$ confidence limits. discrepancy, including uncertainties associated with aerosol emission factors, optical properties, and lifetimes. These issues extend across multiple models (Matichuk et al., 2008) and will require substantial additional effort to resolve. In this context, the climate responses we discuss below are probably more representative of what would be expected for a moderate rather than a strong El Niño.

The maximum AOD simulated by CAM occurred at the same time as the maximum in fire emissions (Fig. 3b). This timing is consistent with observed AODs that showed no lag relative to emissions (Fig. 1c, d). The higher emissions increased the absorbing aerosol optical depth, which constituted 7\% (and as much as 10\%) of the total increase in regional aerosol optical depth for the August-October period. In response to the aerosol forcing, all-sky net surface shortwave radiation $\left(\mathrm{S}_{\text {net }}\right)$ decreased by $19.1 \pm 12.9 \mathrm{~W} \mathrm{~m}^{-2}(10 \%)$ from $192.4 \mathrm{~W} \mathrm{~m}^{-2}$ to $173.3 \mathrm{~W} \mathrm{~m}^{-2}$ during August-October (Fig. 3c, Table 1). This strong surface darkening was offset by moderate shortwave heating anomaly $\left(20.5 \pm 9.3 \mathrm{~W} \mathrm{~m}^{-2}\right)$ throughout the atmospheric column. At the top of the atmosphere the net all-sky radiative forcing was nearly zero as a consequence of the combined effect of OC scattering and BC absorption.

The decrease in $\mathrm{S}_{\text {net }}$ had several effects, including a $0.5 \pm 0.3{ }^{\circ} \mathrm{C}$ average reduction in regional sea surface temperatures (SSTs) and $0.4 \pm 0.2^{\circ} \mathrm{C}$ reduction of land surface temperature during August-October (Fig. 3, Table 1). The SST response was delayed by approximately 1 month relative to the AOD forcing, with the largest decrease occurring during October $\left(0.7 \pm 0.1^{\circ} \mathrm{C}\right)$ and with decreases in November $\left(0.4 \pm 0.1^{\circ} \mathrm{C}\right)$ exceeding those in August $\left(0.3 \pm 0.1^{\circ} \mathrm{C}\right)$. The largest SST reductions occurred in the region between Sumatra and Borneo (Fig. 5a), where aerosol optical depths were also at a maximum (Fig. 4c).

In the tropics, deep convection (and, by proxy, surface convergence) occurs most often in regions with the highest SSTs, and generally requires SSTs greater than $26^{\circ} \mathrm{C}$ (Graham and Barnett, 1987). Zhang (1993) show that the probability of relatively low outgoing longwave radiation (OLR) values, often associated with deep convection, increases for SSTs between $26^{\circ} \mathrm{C}$ and $29^{\circ} \mathrm{C}$, is at a maximum between $29^{\circ} \mathrm{C}$ and $30^{\circ} \mathrm{C}$, and then decreases for SSTs greater than $30^{\circ} \mathrm{C}$. SSTs decreased from $28.6^{\circ} \mathrm{C}$ in the low fire simulation to $28.1{ }^{\circ} \mathrm{C}$ in the high fire simulation (Table 1). As described below, the decreases in convection observed within the model were consistent with these empirically derived relationships from SST.

On average, August-October surface divergence increased by $0.2 \times 10^{-6} \mathrm{~s}^{-1}$, but showed a mixed pattern with increases over the eastern part of the Indian Ocean, Sumatra and over the ocean between Sumatra and Borneo, but decreases over the island of Borneo (Fig. 5b, Table 1). Analysis of the seasonal cycle from the low fire simulation showed that surface divergence peaked in May $\left(-0.9 \times 10^{-6} \mathrm{~s}^{-1}\right)$, corresponding to the month of lowest simulated precipitation, and declined 
Table 1. Fire aerosol effects on climate in equatorial Asia ${ }^{\mathrm{a}}$

\begin{tabular}{|c|c|c|c|c|}
\hline & High-fire simulation & Low-fire simulation & Difference (high-low) & $\%$ change \\
\hline $\mathrm{BC}$ and $\mathrm{OC}$ emissions ${ }^{b}$ (sum; Tg month ${ }^{-1}$ ) & 3.0 & 0.2 & 2.8 & \\
\hline BC and OC aerosol optical depth (AOD) & 0.4 & 0.0 & 0.4 & \\
\hline All-sky net surf. SW flux $\left(\mathrm{S}_{n e t} ; \mathrm{W} \mathrm{m}^{-2}\right)$ & 173.3 & 192.4 & -19.1 & -10 \\
\hline Sea surface temperature $\left(\mathrm{SST} ;{ }^{\circ} \mathrm{C}\right)$ & 28.1 & 28.6 & -0.5 & \\
\hline Land surface temperature (LST; ${ }^{\circ} \mathrm{C}$ ) & 25.3 & 25.8 & -0.4 & \\
\hline Divergence $\left(\times 10^{-6} \mathrm{~s}^{-1}\right)$ & -2.9 & -3.2 & 0.2 & 6 \\
\hline Precipitation (PPT) $\left(\mathrm{mm} \mathrm{d}^{-1}\right)$ & 7.9 & 8.8 & -0.9 & -10 \\
\hline Evapotranspiration (ET) $\left(\mathrm{mm} \mathrm{d}^{-1}\right)$ & 4.1 & 4.7 & -0.6 & -13 \\
\hline PPT-ET $\left(\mathrm{mm} \mathrm{d}^{-1}\right)$ & 3.8 & 4.1 & -0.4 & -10 \\
\hline All-sky net trop. SW heating $\left(\mathrm{F}_{S W} ; \mathrm{W} \mathrm{m}^{-2}\right)$ & 100.0 & 79.4 & 20.5 & 26 \\
\hline All-sky net atm. SW heating $\left(\mathrm{W} \mathrm{m}^{-2}\right)$ & 119.4 & 96.2 & 23.2 & 24 \\
\hline Net trop. condensational heating $\left(\mathrm{F}_{L H} ; \mathrm{W} \mathrm{m}^{-2}\right)$ & 212.2 & 237.2 & -25.1 & -11 \\
\hline All-sky net trop. $\mathrm{LW}$ heating $\left(\mathrm{F}_{L W} ; \mathrm{W} \mathrm{m}^{-2}\right)$ & -145.5 & -145.3 & -0.2 & -0.1 \\
\hline$\Sigma \mathrm{F}_{S W}+\mathrm{F}_{L H}+\mathrm{F}_{L W}\left(\mathrm{~W} \mathrm{~m}^{-2}\right)$ & 166.7 & 171.3 & -4.6 & -3 \\
\hline Net atm. SW forcing (aerosols) $)^{c}\left(\mathrm{~W} \mathrm{~m}^{-2}\right)$ & 24.4 & 1.1 & 23.3 & \\
\hline All-sky TOA SW aerosol forcing $\left(\mathrm{W} \mathrm{m}^{-2}\right)$ & 2.8 & -0.4 & 3.2 & \\
\hline Tropospheric $q$ (specific humidity; $\mathrm{g} \mathrm{kg}^{-1}$ ) & 5.8 & 5.8 & no change & no change \\
\hline Surface $q\left(\mathrm{~g} \mathrm{~kg}^{-1}\right)$ & 18.1 & 18.4 & -0.3 & 2 \\
\hline Convective Cloud Fraction at $700 \mathrm{mb}(\%)$ & 19.7 & 20.2 & -1 & -7 \\
\hline
\end{tabular}

${ }^{a}$ Reported values are the means from CAM simulations over the region spanned by $90^{\circ} \mathrm{E}-120^{\circ} \mathrm{E}$ and $5^{\circ} \mathrm{S}-5^{\circ} \mathrm{N}$ for August-October.

$\mathrm{b}$ We used fire emissions from the Global Fire Emissions Database, version 2 (GFEDv2) (van der Werf et al., 2006).

c The calculated all-sky atmospheric SW heating was estimated from aerosol direct absorption only.

steadily for the rest of the year. The timing and magnitude of the maximum in surface divergence was similar in the high fire simulation. However, the onset of fires in August forced another, albeit smaller, relative peak in October $\left(-2.6 \times 10^{-6} \mathrm{~s}^{-1}\right)$, suggesting that the fires slowed or suppressed the regular increase in tropical covergence.

Convection is not solely controlled by surface convergence, but also by surface latent heat fluxes and wind speed (Raymond, 1995). Surface specific humidity declined by a small amount $\left(0.3 \pm 0.1 \mathrm{~g} \mathrm{~kg}^{-1}\right)$ likely in response to lowered saturation vapor pressure in a cooler atmosphere, and reduced evaporation from cooler land and sea surfaces.

In addition to the effect of fire aerosols on surface temperature, black carbon absorption of solar radiation from fireemitted aerosols caused an anomalous warming in the troposphere. The all-sky shortwave heating anomaly in the troposphere was $20.5 \pm 9.3 \mathrm{~W} \mathrm{~m}^{-2}$ for August-October (Table 1), and corresponded to substantial shortwave warming between $300 \mathrm{mb}$ and $700 \mathrm{mb}$ (Fig. 6a). The entire atmospheric column heating was $23.2 \pm 9.3 \mathrm{~W} \mathrm{~m}^{-2}$. In the absence of atmospheric feedbacks the aerosol-forced shortwave heating rate for the total column was $23.3 \pm 9.2 \mathrm{~W} \mathrm{~m}^{-2}$ for the high fire simulation (Table 1). This suggests that the increased shortwave heating between the two simulations was almost exclusively a consequence of $\mathrm{BC}$ and $\mathrm{OC}$ absorption. The radiative warming was balanced by a decrease in condensational heating of $25.1 \pm 11.2 \mathrm{~W} \mathrm{~m}^{-2}$ through the troposphere (Table 1, Fig. 6b). Combined with a modest longwave cooling $\left(0.2 \pm 4.3 \mathrm{~W} \mathrm{~m}^{-2}\right)$ (Fig. 6c), the net effect was a small cooling (4.6 $\pm 15.2 \mathrm{~W} \mathrm{~m}^{-2}$; Fig. 6d).

The decrease in condensation did not significantly reduce total column water vapor (Table 1). However, as noted above, surface humidity decreased $0.3 \mathrm{~g} \mathrm{~kg}^{-1}$ due to cooler air and sea temperatures. The reduced latent heating and surface humidity accompanied a significant reduction in atmospheric deep convection.

Increased tropospheric subsidence was greatest during September and October in the lower troposphere $(<700 \mathrm{mb})$, and during November in the mid troposphere (200$700 \mathrm{mb}$ ) (Fig. 7a). At the $700 \mathrm{mb}$ level, anomalies were $4.9 \times 10^{-3} \mathrm{~m} \mathrm{~s}^{-1}$ for the August-October period. This indicated a reduction of convective updrafts, possibly causing the simulated decreases in high-level clouds and increases in mid-level clouds (Fig. 7b). Due to increased subsidence and decreased condensation (especially above $900 \mathrm{mb}$ ) convective cloud cover decreased uniformly throughout the troposphere (Fig. 7c). Averaged over the study area, $700 \mathrm{mb}$ convective cloud cover decreased from $20.2 \%$ to $18.7 \%$, corresponding to $7 \%$ relative reduction (Table 1 ).

The suppression of deep convection reduced precipitation by $0.9 \pm 0.6 \mathrm{~mm} \mathrm{~d}^{-1}$ (10\%; Fig. 3e). The maximum precipitation decrease occurred over Sumatra, downwind of high 


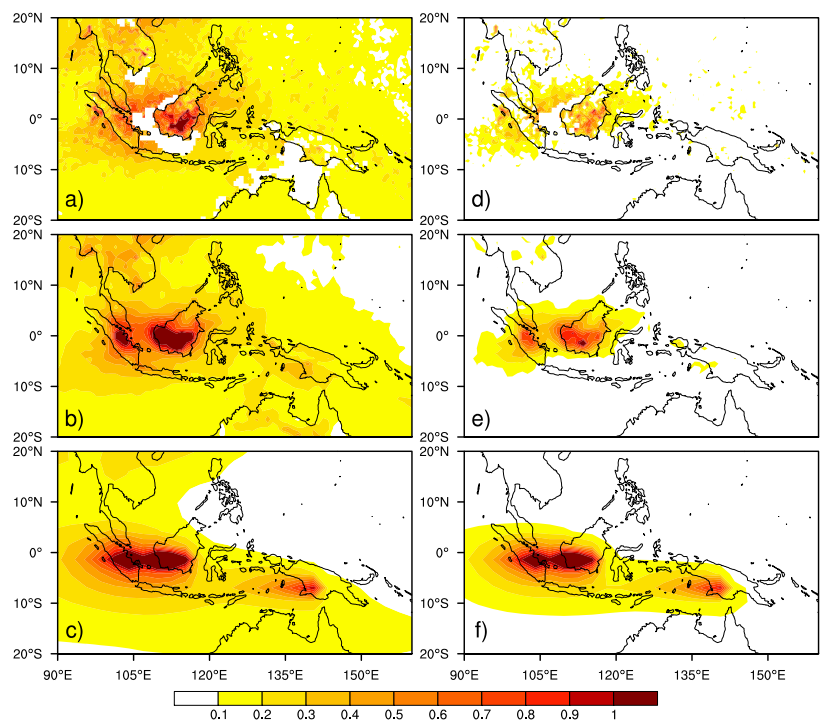

Fig. 4. Aerosol optical depths from satellite and model simulations during high and low fire years. (a) August-October mean AOD from MISR for moderate El Niño years (the mean of 2002, 2004, and 2006), (b) MODIS AOD for same period, (c) CAM-simulated AOD for the high fire simulation (forced with 1997 emissions), (d) The difference in August-October MISR AOD between moderate El Niño (2002, 2004, 2006) and La Niña (2000, 2001, 2005) years, (e) MODIS AOD differences for the same two periods, (f) CAMsimulated AOD for the difference between the high fire and low fire simulations.

fire activity on Borneo (Fig. 5). As with the decrease in SSTs, the precipitation response lagged the fire forcing by approximately 1 month. The largest decreases occurred during October $\left(1.3 \pm 0.3 \mathrm{~mm} \mathrm{~d}^{-1} ; 15 \%\right)$, with reductions during November $\left(0.8 \pm 1.2 \mathrm{~mm} \mathrm{~d}^{-1} ; 9 \%\right)$ exceeding those for $\mathrm{Au}-$ gust $\left(0.2 \pm 0.4 \mathrm{~mm} \mathrm{~d}^{-1} ; 3 \%\right)$. Regional evapotranspiration decreased in parallel, by $0.6 \pm 0.2 \mathrm{~mm} \mathrm{~d}^{-1}$ during AugustOctober (Fig. 3e, Table 1). Because decreases in evapotranspiration were not as large as decreases in precipitation (Figs. 3e and 5d), moisture content for the top layer of soil decreased on Borneo and Sumatra.

Precipitation response to the enhanced aerosol forcing was larger over the southern parts of Borneo and Sumatra (south of $1^{\circ} \mathrm{S}$ ) where most fire emissions originated. Similar to the region as a whole, the precipitation response in southern Borneo lagged the aerosol forcing by one month, with the largest negative precipitation anomalies occurring in October $\left(1.6 \pm 0.3 \mathrm{~mm} \mathrm{~d}^{-1} ; 17 \%\right)$ and November $\left(1.4 \pm 0.5 \mathrm{~mm} \mathrm{~d}^{-1}\right.$; $16 \%)$. Averaged over the fire season during August-October, the precipitation reduction was $1.1 \pm 0.5 \mathrm{~mm} \mathrm{~d}^{-1}(13 \%)$. Precipitation anomalies in southern Sumatra were even larger, in terms of both absolute changes and relative differences. Decreases during September and October were 3.1 \pm 0.7 and $3.1 \pm 0.5 \mathrm{~mm} \mathrm{~d}^{-1}$, respectively, corresponding to relative changes of $31 \%$ and $28 \%$. In contrast with earlier work showing that in South Asia aerosols caused increases in precipitation in some months but decreases them in others (Ramanathan and Carmichael, 2008), we did not observe any months in which precipitation increased significantly.

To obtain a preliminary estimate of the impact of these precipitation changes on regional fire emissions, we compared our model results with the precipitation-fire emissions relationship derived by van der Werf et al. (2008) for the southern part of Borneo using satellite observations and as shown in Fig. 2 of van der Werf et al. (2008). As described above, our aerosol forcing in CAM was similar to that observed during moderate El Niño events (e.g. Fig. 4) and led to a 13\% reduction in precipitation during the dry season (August-October) in southern Borneo. We additionally note that the mean precipitation during the dry season in southern Borneo during three recent moderate El Niño events (2002, 2004, and 2006) was $62 \mathrm{~mm} \mathrm{month}^{-1}$ based on TRMM observations. Using the precipitation sensitivity to fire-emitted aerosols from CAM, and the fire emissions sensitivity to precipitation from van der Werf (2008) we estimated that if no fires occurred during these recent El Niño events, dry season precipitation would have been higher, with a mean of $72 \mathrm{~mm}$ month $^{-1}$. In terms of fire emissions, the aerosol-climate feedback quantified here may have increased fire emissions during these recent moderate El Niño events by approximately $46 \%$ (from $73 \mathrm{Tg} \mathrm{C} \mathrm{yr}^{-1}$ to $107 \mathrm{Tg} \mathrm{Cyr}^{-1}$ ). We note that this estimate is qualitative, and that future work to improve our understanding of this feedback should include aerosol indirect effects and prognostic fire emissions (so that fires respond to precipitation interactively during the dry season and from year to year). It is also important to note that the near-exponential relationship between dry season precipitation and emissions (van der Werf et al., 2008) is based on observations and so it already has fire-aerosol-climate feedbacks embedded within it. As a consequence, the sensitivity of fire emissions to aerosol-mediated climate changes presented here is likely an upper bound.

\section{Discussion}

Elevated fire aerosol concentrations caused a reduction in convection and precipitation in equatorial Asia in simulations with CAM. The direct aerosol effect cooled the surface which reduced specific humidity, surface convergence, and contributed to increased static stability. Stability also was enhanced by increased heating of the troposphere from $\mathrm{BC}$ absorption of shortwave radiation. The combined effect of these changes reduced atmospheric convection. The resulting reduction of condensational heating was roughly balanced by increased shortwave heating due to smoke absorption, leading to very little change in air temperature in the mid troposphere.

These mechanisms for precipitation reduction are consistent with past work that has linked regional sea surface 
a) Temperature

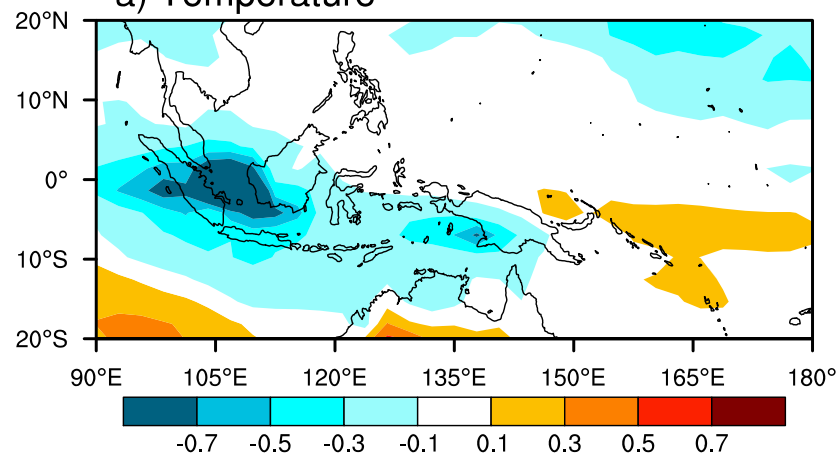

c) Precipitation

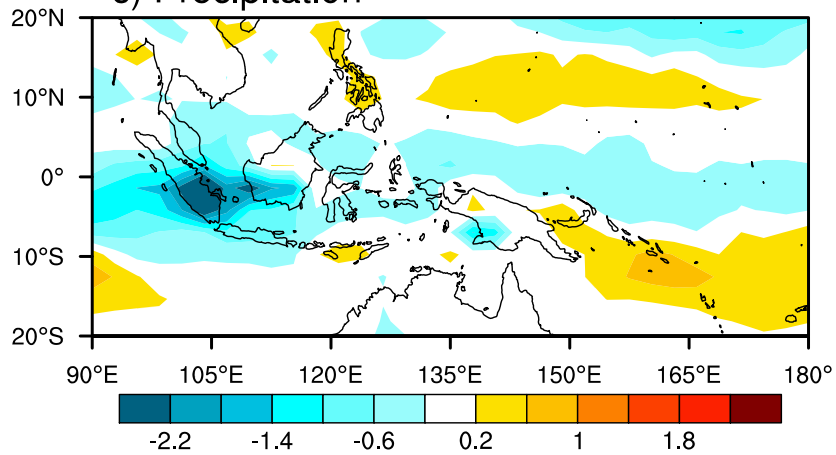

b) Divergence and wind

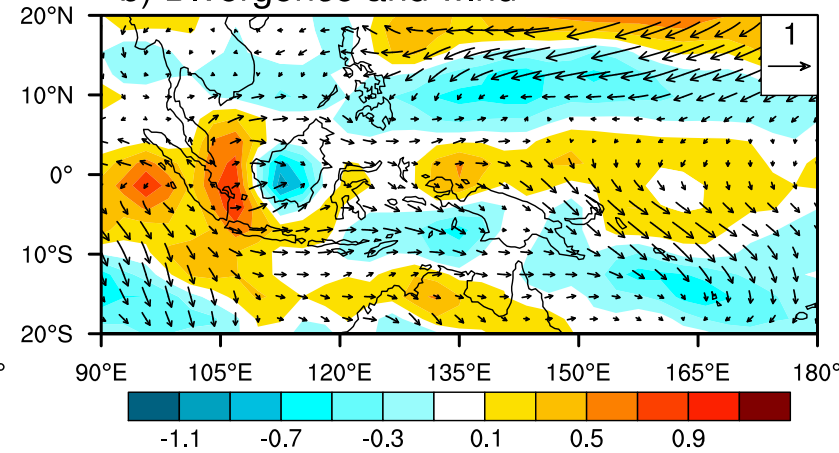

d) Precipitation -- evapotranspiration

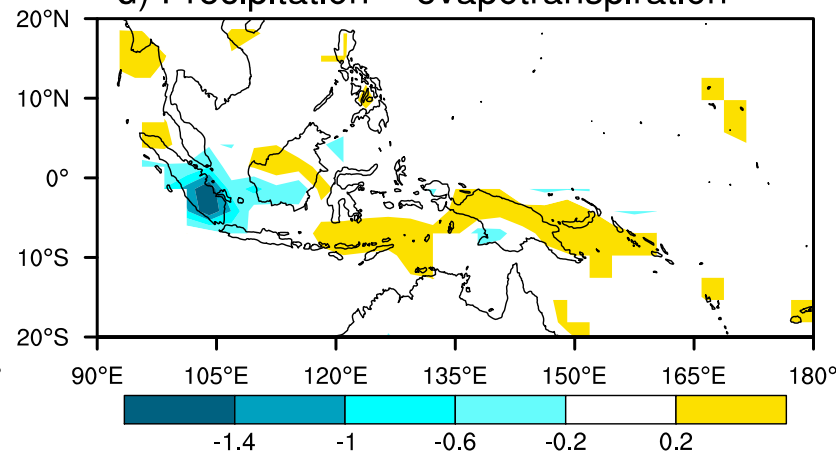

Fig. 5. (a) August-October simulated surface temperature anomalies $\left({ }^{\circ} \mathrm{C}\right)$, (b) surface divergence $\left(\mathrm{s}^{-1}\right)$, wind speed $\left(\mathrm{m} \mathrm{s}^{-1}\right)$ and wind direction anomalies, (c) modeled precipitation $\left(\mathrm{mm} \mathrm{d}^{-1}\right)$ anomalies, and (d) precipitation minus evapotranspiration anomalies $\left(\mathrm{mm} \mathrm{d}^{-1}\right)$. All plots are the mean difference between the high and low fire simulations averaged during August-October. Positive surface divergence anomalies (b) are indicated by red and yellow shading, and are associated with decreased convection.

cooling with increases in surface pressure and decreases in surface convergence (Graham and Barnett, 1987; Hackert and Hastenrath, 1986). Cooler surface temperatures and resulting decreases in surface wind speeds combine to limit surface convergence (Chelton et al., 2004). Raymond (1995) showed that lower surface wind speeds over the western Pacific are observationally linked with reduced convection, a relationship also observed in our simulations.

Both empirical and modeling studies on atmospheric aerosols provide evidence that our model responses to fireemitted aerosols are reasonable. Measurements over the Indian Ocean during 1998 and 1999 as part of the INDian Ocean EXperiment (INDOEX) show that aerosol atmospheric heating reduced subtropical cumulus cloud coverage by $25 \%$ and $40 \%$ (Ackerman et al., 2000). Similarly, Koren et al. (2004) showed that cloud cover in the Amazon decreased 50\% in response to AODs of approximately 0.6 during the months of August-September 2002. In comparison, here we found a $7.5 \%$ decrease in convective clouds in response to elevated AODs of 0.4 for our study region. This is consistent with results from Cook and Highwood (2003) who used an intermediate general-circulation model to show that convective cloud cover decreases in response to increases in static stability caused by absorbing aerosols.
Our results demonstrate a plausible positive feedback loop between fire and climate in equatorial Asia. Satellite observations linked drought, fires and elevated AODs during moderate El Niño events (Fig. 2). Elevated AODs, in turn, reduced both regional precipitation and soil moisture in simulations with CAM. The average precipitation decrease for Sumatra and Borneo was approximately $10 \%$ during the dry season, with even larger reductions over source regions (Fig. 4). Multiple mechanisms probably contributed to the precipitation reduction, including increased atmospheric stability from absorbing aerosols in the mid troposphere and decreased surface temperatures. Thus, regional climate responses to fire-emitted aerosols increased drought stress in terrestrial ecosystems, and would make it easier for farmers to use fire as a tool in converting forests and peatlands to agriculture. The time scale for these interactions was over a period of months during the dry season with very little carry over observed during the following wet season (JanuaryMay) (Fig. 3). Given that our model substantially underestimated fire-induced changes in AOD, it is likely that our simulations did not represent the full atmospheric response to fires during the 1997 El Niño. 

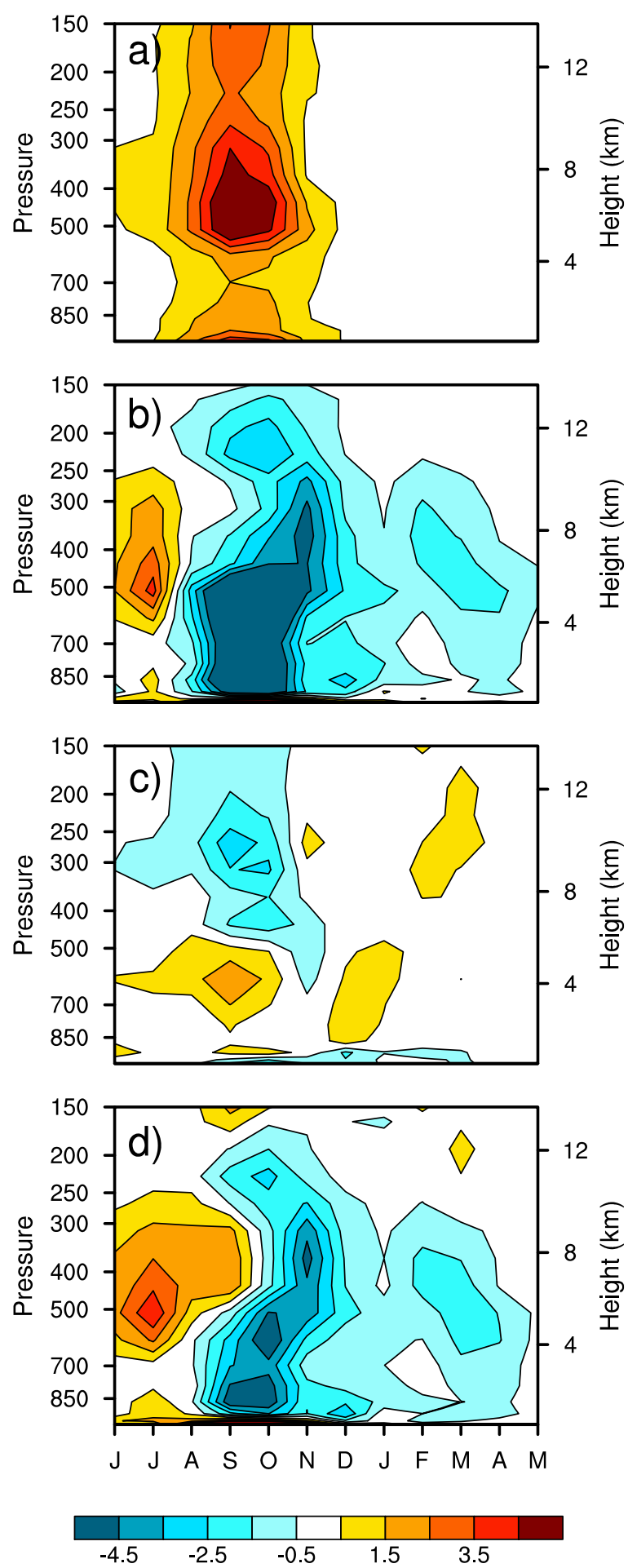

Fig. 6. Fire-induced anomalies in the (a) shortwave warming rate $\left({ }^{\circ} \mathrm{C}\right.$ day $\left.^{-1}\right)$, (b) condensational warming rate $\left({ }^{\circ} \mathrm{C}\right.$ day $\left.{ }^{-1}\right)$, (c) longwave warming rate $\left({ }^{\circ} \mathrm{C} \mathrm{day}{ }^{-1}\right)$, and (d) the sum of shortwave, condensational and longwave components (sum of panels a-c above; units of ${ }^{\circ} \mathrm{C} \mathrm{day}{ }^{-1}$ ). The plots show the mean model response for the $90^{\circ} \mathrm{E}-120^{\circ}, 5^{\circ} \mathrm{S}-5^{\circ} \mathrm{N}$ region for an annual cycle beginning in June and ending in May a) Vertical wind velocities

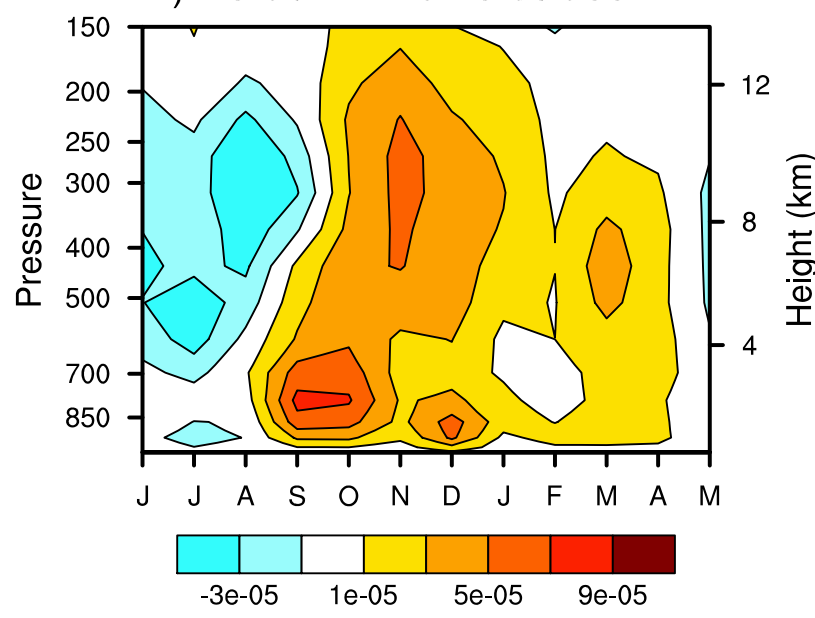

b) Total cloud fraction

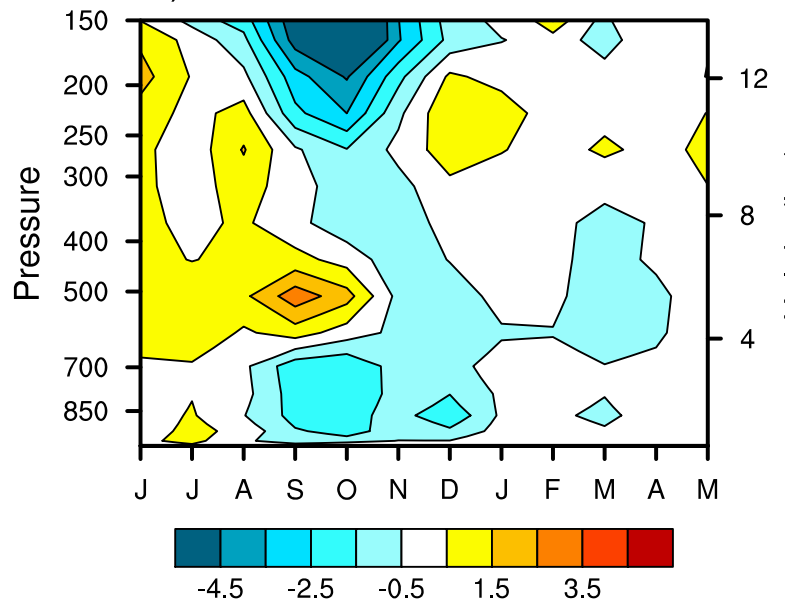

c) Convective cloud fraction

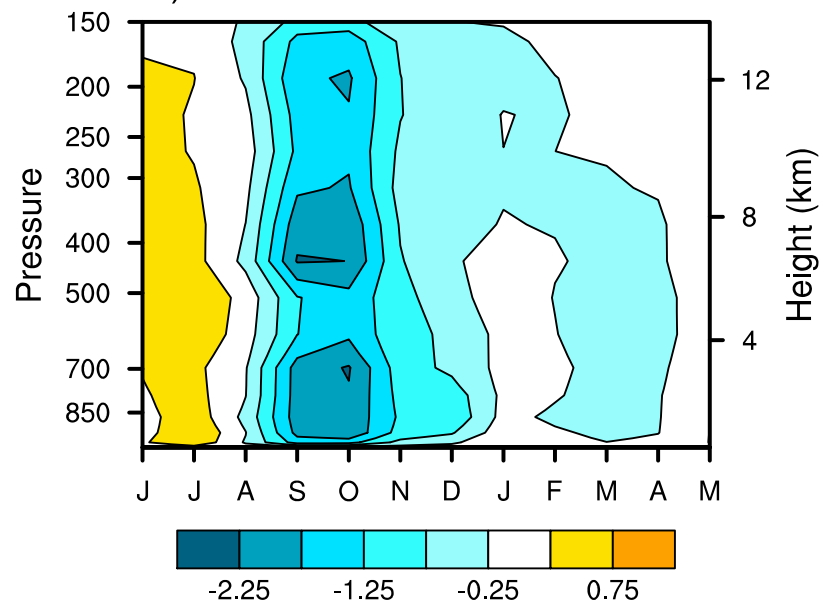

Fig. 7. Simulated fire-induced anomalies in (a) vertical velocity $\left(\mathrm{mb} \mathrm{s}^{-1}\right),(\mathbf{b})$ total cloud cover $(\%)$ and (c) convective cloud cover (\%). Positive vertical velocity anomalies represent stronger downdrafts. Analysis region is the same as in Fig. 6. 
An interesting question raised by this analysis is whether fire-emitted aerosols influence El Niño dynamics over a period of years to decades. A unique aspect of the fire-aerosol forcing in this region is that it is phase locked with El NiñoSouthern Oscillation dynamics through the sensitivity of fire emissions to drought (e.g. Fig. 1). It is also a relatively recent forcing, strengthening over only a period of several decades as a consequence of migration and agricultural development in Indonesia (Field et al., 2009). Memory of aerosol effects in the climate system over a period of years may occur through altered patterns of ocean heat storage, thus requiring the use of a fully coupled ocean-atmosphere general circulation model to study these interactions. Past work has considered how ENSO may respond to regional aerosols, but primarily from the perspective of a stationary forcing associated with fossil and biofuel aerosol emission sources from South Asia. Emissions from South Asia, although larger in magnitude, probably do not have the same sensitivity to regional drought. Chung and Ramanathan (2002), for example, find that long-term tropospheric warming from the South Asian aerosol cloud increases precipitation over the North Indian Ocean by modifying the north-south temperature gradient in the Indian Ocean. The resulting northward shift of the ITCZ subsequently suppresses precipitation in equatorial Asia. Chung et al. (2002) provide evidence that convection suppression over equatorial Asia may influence ENSO dynamics. They propose that convection suppression in the western Pacific leads to weaker trade winds throughout the equatorial Pacific. This allows for a deepening of the thermocline in the east and a transition to El Niño-like conditions.

The absence of an interactive cloud microphysical response to aerosols in CAM3 introduces several limitations to our analysis. Several studies show a reduction in precipitation in response to aerosol indirect effects (Rosenfeld, 1999, 2000; Khain et al., 2001). This is especially true in clouds dominated by warm-rain processes (Rosenfeld et al., 2006, 2008). These mechanisms might potentially enhance the positive feedback loop between fire and drought described above. Lin et al. (2006) and Rosenfeld et al. (2008) provide evidence, however, that for deep convection aerosol indirect effects may instead invigorate updrafts and therefore increase precipitation.

There are other pathways by which absorbing aerosols might enhance precipitation. Menon et al. (2002), for example, suggest that increased $\mathrm{BC}$ absorption enhances convection over mid-latitude China. Results from a similar study by Chung et al. (2002) show that the introduction of absorbing aerosols into a relatively stable atmosphere heats the troposphere at low levels but that widespread heating does not extend above $700 \mathrm{mb}$. This low-altitude heating destabilizes the atmosphere above, as shown by peak vertical velocities occurring above $700 \mathrm{mb}$ in both studies. In contrast, our study region was initially unstable throughout the column, allowing aerosols introduced at the surface to disperse through- out the troposphere, not just at lower altitudes. Widespread heating was simulated well above $700 \mathrm{mb}$ and ultimately prevented the development of mid-tropospheric instability.

Our ability to accurately simulate the mesoscale meteorology of the Indonesian archipelago also was limited by the coarse resolution of CAM3 and the unique geography of the area. The region receives over $50 \%$ of its rainfall from convective activity (Mori et al., 2004; Chen and Houze, 1997), and interactions between island topography and the open ocean fuel diurnal and regional variations in precipitation. As a result of the daytime sea breeze, rainfall rates on land are greatest during the late afternoon and early evening coinciding with the timing of maximum boundary layer height (Mori et al., 2004; Schafer et al., 2001; Chen and Houze, 1997). Most of the island rainfall is the result of isolated convective clouds. After sunset, convection over land aggregates to form mesoscale convective complexes, which move over the ocean and increase offshore rainfall rates during the early morning (Mori et al., 2004; Williams and Houze, 1987). During the Northern Hemisphere winter, the diurnal amplitude of convection can be three times greater over the islands than the adjacent ocean, owing to the smaller heat capacity of land and subsequent variations in low-level instability (Yang and Slingo, 2001). The active phase of the Madden-Julian Oscillation (MJO) suppresses the amplitude of the diurnal cycle (Sui and Lau, 1992). In turn, the Indonesian archipelago alters the strength and speed of the MJO. Neale and Slingo (2003) conclude that even with a threefold increase in horizontal resolution there is little improvement in regional rainfall simulation in a global climate model. Our results suggest that an increase in absorption and scattering from smoke aerosols weakens the lapse rate. We acknowledge the difficulty of accurately representing the spatial and temporal pattern of the resulting precipitation decreases in our model due to challenges in simulating the mesoscale processes in the region. In the future, higher resolution simulations (that include aerosol indirect effects) will be needed to reduce uncertainties associated with the fire-climate feedbacks described here.

\section{Conclusions}

We used a combination of satellite observations and modeling to study interactions between fires, aerosols, and climate in equatorial Asia. Analysis of satellite observations showed that aerosol optical depths in the region were highly variable from year-to-year and were driven by deforestation fires during periods of El Niño-induced drought. Simulations with a climate model showed, in turn, that fire-emitted aerosols can suppress convection and precipitation by increasing atmospheric stability and decreasing surface temperatures. Together, the observations and model simulations provide evidence for a possible feedback loop in which anthropogenic 
fire emissions during El Niño events intensify drought over source regions.

Important next steps include assessing the sensitivity of convection and precipitation in the region to aerosol indirect effects and devising innovative ways to use remote sensing observations to test more aspects of the positive feedback loop described above. An intriguing future direction is to study whether aerosol forcing by these fires can alter ENSO dynamics on decadal timescales.

Acknowledgements. We are grateful for support from NSF (ATM0628637) and NASA (NNX08AF64G). M. G. T. received support from a NASA Earth and Space Science Fellowship (08-Earth08F189). C. S. Z. acknowledges NSF (ARC-0714088) and NASA (NNX07AR23G) support.

Edited by: A. Hofzumahaus

\section{References}

Ackerman, A. S., Toon, O. B., Stevens, D. E., Heymsfield, A. J., Ramanathan, V., and Welton, E. J.: Reduction of tropical cloudiness by soot, Science, 288, 1042-1047, doi:10.1126/science. 288 . 5468.1042, 2000.

Adler, R. F., Huffman, G. J., and Chang, A.: The Version-2 Global Precipitation Climatology Project (GPCP) monthly precipitation analysis (1979-present), J. Hydrometeor., 4, 1147-1167, 2003.

Andreae, M. O. and Merlet, P.: Emission of trace gases and aerosols from biomass burning, Global Biogeochem. Cy., 15, 955-966, 2001.

Bond, T. C., Habib, G., and Bergstrom, R. W.: Limitations in the enhancement of visible light absorption due to mixing state, J. Geophys. Res., 111, D20211, doi:10.1029/2006JD007315, 2006.

Bowen, M. R., Bompard, J. M., Anderson, I. P., Guizol, P., and Gouyon, A.: Anthropogenic fires in Indonesia: A view from Sumatra, in: Forest Fires and Regional Haze in Southeast Asia, edited by Peter, E. and Radojevic, M., Nova Science Publishers, 41-66, 2001.

Bowman, D. M. J. S., Balch, J. K., Artaxo, P., Bond, W. J., Carlson, J. M., Cochrane, M. A., D’Antonio, C. M., DeFries, R. S., Doyle, J. C., Harrison, S. P., Johnston, F. H., Keeley, J. E., Krawchuk, M. A., Kull, C. A., Marston, J. B., Moritz, M. A., Prentice, I. C., Roos, C. I., Scott, A. C., Swetnam, T. W., van der Werf, G. R., and Pyne, S. J.: Fire in the Earth system, Science, 324, 481-484, doi:10.1126/science.1163886, 2009.

Chelton, D. B., Schlax, M. G., Freilich, M. J., and Milliff, R. F.: Satellite measurements reveal small-scale features in ocean winds, Science, 303, 978-983, doi:10.1126/science.1091901, 2004.

Chen, S. S. and Houze, R. A.: Diurnal variation and life-cycle of deep convective systems over the tropical Pacific warm pool, Q. J. Roy. Meteorol. Soc., 123, 357-388, 1997.

Chung, C. E. and Ramanathan, V.: South Asian haze forcing: Remote impacts with implications to ENSO and AO, J. Clim., 16, 1791-1805, 2002.

Chung, C. E., Ramanathan, V., and Kiehl, J. T.: Effects of the South Asian absorbing haze on the northeast monsoon and surface-air heat exchange, J. Clim., 15, 2462-2476, 2002.
Chylek, P. and Coakley, J. A.: Aerosols and climate, Science, 183, 75-77, 1974.

Collins, W. D., Rasch, P. J., Eaton, B. E., Fillmore, D. W., and Kiehl, J. T.: Simulation of aerosol distributions and radiative forcing for INDOEX: Regional climate impacts, J. Geophys. Res., 107, 8028, doi:10.1029/2000JD000032, 2002.

Collins, W. D., Rasch, P. J., Boville, B. A., Hack, J. J., McCaa, J. R., Williamson, D. L., Kiehl, J. T., and Briegleb, B.: Description of the Community Atmosphere Model (CAM 3.0), Tech. Rep. NCAR TN-464+STR, National Center for Atmospheric Research, 226 pp., 2004.

Cook, J. and Highwood, E. J.: Climate response to tropospheric absorbing aerosols in an intermediate general-circulation model, Q. J. Roy. Meteorol. Soc., 1, 1-20, doi:10.1256/qj.03.64, 2003.

Duncan, B. N., Bey, I., Chin, M., Mickley, L. J., Fairlie, T. D., Martin, R. V., and Matsueda, H.: Indonesia wildfires of 1997: Impact on tropospheric chemistry, J. Geophys. Res., 108, 4458, doi:10.1029/2002JD003195, 2003.

Field, R. D., van der Werf, G. R., and Shen, S. S. P.: Human amplification of drought-induced biomass burning in Indonesia since 1960, Nat. Geosci., 2, 185-188, doi:10.1038/NGEO443, 2009.

Flanner, M. G., Zender, C. S., Randerson, J. T., and Rasch, P. J.: Present-day climate forcing and response from black carbon in snow, J. Geophys. Res., 112, D11 202, doi:10.1029/ 2006JD008003, 2007.

Giglio, L., van der Werf, G. R., Randerson, J. T., Collatz, G. J., and Kasibhatla, P. S.: Global estimation of burned area using MODIS active fire observations, Atmos. Chem. Phys., 6, 957-974, 2006, http://www.atmos-chem-phys.net/6/957/2006/.

Graham, N. E. and Barnett, T. P.: Sea surface temperature, surface wind divergence, and convection over tropical oceans, Science, 238, 657-659, 1987.

Hackert, E. C. and Hastenrath, S.: Mechanisms of Java rainfall anomalies, Mon. Weather Rev., 114, 745-757, 1986.

Hansen, J. E., Sato, M., and Ruedy, R.: Radiative forcing and climate response, J. Geophys. Res., 102, 6831-6864, 1997.

Hansen, M. C., Stehman, S. V., Potapov, P. V., Loveland, T. R., Townshend, J. R. G., Defries, R. S., Pittman, K. W., Arunarwati, B., Stolle, F., Steininger, M. K., Carroll, M., and DiMiceli, C.: Humid tropical forest clearing from 2000 to 2005 quantified by using multitemporal and multiresolution remotely sensed data, Proc. Natl. Acad. Sci., 105, 9439-9444, doi:10.1073/pnas. 0804042105, 2008.

Haywood, J. M. and Shine, K. P.: The effect of anthropogenic sulfate and soot aerosol on the clear sky planetary radiation budget, Geophys. Res. Lett., 22, 603-606, 1995.

Heil, A. and Goldammer, J. G.: Smoke-haze pollution: A review of the 1997 episode in Southeast Asia, Reg. Environ. Ch., 2, 24-37, doi:10.1007/s101130100021, 2001.

Heil, A., Langmann, B., and Aldrian, E.: Indonesian peat and vegetation fire emissions: Study on factors influencing large-scale smoke haze pollution using a regional atmospheric chemistry model, Mitig. Adapt. Strat. Glob. Change, 12, 113-133, doi: 10.1007/s11027-006-9045-6, 2005.

Khain, A., Rosenfeld, D., and Pokrovsky, A.: Simulating convective clouds with sustained supercooled liquid water down to $-37.5^{\circ} \mathrm{C}$ using a spectral microphysics model, Geophys. Res. Lett., 28, 3887-3890, 2001.

Koren, I., Kaufman, Y. J., Remer, L. A., and Martins, J. V.: 
Measurement of the effect of Amazon smoke on inhibition of cloud formation, Science, 303, 1342-1345, doi:10.1126/science. 1089424, 2004.

Kummerow, C., Barnes, W., Kozu, T., Shiue, J., and Simpson, J.: The Tropical Rainfall Measuring Mission (TRMM) sensor package, J. Atmos. Ocean. Tech., 15, 809-817, 1998.

Langenfelds, R. L., Francey, R. J., Pak, B. C., Steele, L. P., Lloyd, J., Trudinger, C. M., and Allison, C. E.: Interannual growth rate variations of atmospheric $\mathrm{CO}_{2}$ and its $\delta^{13} \mathrm{C}, \mathrm{H}_{2}, \mathrm{CH}_{4}$, and $\mathrm{CO}$ between 1992 and 1999 linked to biomass burning, Glob. Biogeochem. Cy., 16, 1048, doi:10.1029/2001GB001466, 2002.

Lau, K. M. and Kim, K. M.: Observational relationships between aerosol and Asian monsoon rainfall, and circulation, Geophys. Res. Lett., 33, L21810, 2006.

Liepert, B. G., Feichter, J., Lohmann, U., and Roeckner, E.: Can aerosols spin down the water cycle in a warmer and moister world?, Geophys. Res. Lett., 31, L06207, doi:10.1029/ 2003GL019060, 2004.

Lin, J. C., Matsui, T., Pielke Sr., R. A., and Kummerow, C.: Effects of biomass-burning-derived aerosols on precipitation and clouds in the Amazon Basin: A satellite-based empirical study, J. Geophys. Res., 111, D19204, doi:10.1029/2005JD006884, 2006.

Logan, J. A., Megretskaia, I., Nassar, R., Murray, L. T., Zhang, L., Bowman, K. W., Worden, H. M., and Luo, M.: Effects of the 2006 El Niño on tropospheric composition as revealed by data from the Tropospheric Emission Spectrometer (TES), Geophs. Res. Lett., 35, L03816, doi:10.1029/2007GL031698, 2008.

Lyon, B.: The strength of El Niño and the spatial extent of tropical drought, Geophys. Res. Lett., 31, L21204, doi:10.1029/ 2004GL020901, 2004.

Matichuk, R. I., Colarco, P. R., Smith, J. A., and Toon, O. B.: Modeling the transport and optical properties of smoke plumes from South American biomass burning, J. Geophys. Res., 113, D07208, doi:10.129/2007JD009005, 2008.

Menon, S., Hansen, J. E., Nazarenko, L., and Luo, Y.: Climate effects of black carbon aerosols in China and India, Science, 297, 2250-2253, doi:10.1126/science.1075159, 2002.

Mori, S., Hamada, J.-I., Tauhid, Y. I., and Yamanaka, M. D.: Diurnal land-sea rainfall peak migration over Sumatera island, Indonesian Maritime Continent, observed by TRMM satellite and intensive rawinsonde soundings, Mon. Wea. Rev., 132, 20212039, 2004.

Neale, R. and Slingo, J.: The Maritime Continent and its role in the global climate: A GCM study, J. Clim., 16, 834-848, 2003.

Nelson, D. L., Averill, C., Boland, S., Morford, R., Garay, M., Rheingans, B., Thompson, C., Hall, J., Diner, D., and Campbell, H.: MISR INteractive eXplorer (MINX) V1.0 USER'S GUIDE, Jet Propulsion Laboratory; California Institute of Technology, 102 pp., 2008.

Page, S. E., Siegert, F., Rieley, J. O., Boehm, H. D., Jaya, A., and Limin, S.: The amount of carbon released from peat and forest fires in Indonesia during 1997, Nature, 420, 61-65, doi:10.1038/ nature 01131, 2002.

Penner, J. E., Chuang, C. C., and Grant, K.: Climate forcing by carbonaceous and sulfate aerosols, Clim. Dyn., 14, 839-851, 1998.

Podgorny, I. A., Li, F., and Ramanathan, V.: Large aerosol radiative forcing due to the 1997 Indonesian forest fire, Geophys. Res. Lett., 30, 1028, doi:10.1029/2002GL015979, 2003.

Quaas, J., Ming, Y., Menon, S., Takemura, T., Wang, M., Penner,
J. E., Gettelman, A., Lohmann, U., Bellouin, N., Boucher, O., Sayer, A. M., Thomas, G. E., McComiskey, A., Feingold, G., Hoose, C., Kristjánsson, J. E., Liu, X., Balkanski, Y., Donner, L. J., Ginoux, P. A., Stier, P., Grandey, B., Feichter, J., Sednev, I., Bauer, S. E., Koch, D., Grainger, R. G., Kirkevåg, A., Iversen, T., Seland, Ø., Easter, R., Ghan, S. J., Rasch, P. J., Morrison, H., Lamarque, J.-F., Iacono, M. J., Kinne, S., and Schulz, M.: Aerosol indirect effects - general circulation model intercomparison and evaluation with satellite data, Atmos. Chem. Phys., 9, 8697-8717, 2009,

http://www.atmos-chem-phys.net/9/8697/2009/.

Ramanathan, V. and Carmichael, G.: Global and regional climate changes due to black carbon, Nat. Geosci., 1, 221-227, 2008.

Ramanathan, V., Crutzen, P. J., Kiehl, J. T., and Rosenfeld, D.: Indian Ocean Experiment: An integrated analysis of the climate forcing and effects of the great Indo-Asian haze, J. Geophys. Res., 106, 28371-28398, 2001a.

Ramanathan, V., Crutzen, P. J., Kiehl, J. T., and Rosenfeld, D.: Aerosols, climate, and the hydrological cycle, Science, 294, 2119-2124, doi:10.1126/science.1064034, 2001b.

Ramanathan, V., Chung, C., Kim, D., Bettge, T., Buja, L., Kiehl, J. T., Washington, W. M., Fu, Q., Sikka, D. R., and Wild, M. Atmospheric brown clouds: Impacts on South Asian climate and hydrological cycle, Proc. Natl. Acad. Sci., doi:10.1073/pnas. $0500656102,2005$.

Randles, C. A. and Ramaswamy, V.: Absorbing aerosols over Asia: A Geophysical Fluid Dynamics Laboratory general circulation model sensitivity study of model response to aerosol optical depth and aerosol absorption, J. Geophys. Res., 102, 2389523915, 1997.

Rasch, P. J., Collins, W. D., and Eaton, B. E.: Understanding the Indian Ocean Experiment (INDOEX) aerosol distributions with an aerosol assimilation, J. Geophys. Res., 106, 7337-7355, 2001.

Raymond, D. J.: Regulation of moist convection over the West Pacific Warm Pool, J. Atmos. Sci., 52, 3945-3958, 1995.

Rosenfeld, D.: TRMM observed first direct evidence of smoke from forest fires inhibiting rainfall, Geophys. Res. Lett., 26, 31053108, 1999.

Rosenfeld, D.: Suppression of rain and snow by urban and industrial air pollution, Science, 287, 1793-1796, 2000.

Rosenfeld, D., Lensky, I. M., Peterson, J., and Gingis, A.: Potential impacts of air pollution aerosols on precipitation in Australia, Clean Air and Environ. Qual., 40, 43-49, 2006.

Rosenfeld, D., Woodley, W. L., Axisa, D., Freud, E., Hudson, J. G., and Givati, A.: Aircraft measurements of the impacts of pollution aerosols on clouds and precipitation over the Sierra Nevada, J. Geophys. Res., 113, D15203, doi:10.1029/2007JD009544, 2008.

Schafer, R., May, P. T., Keenan, T. D., McGuffie, K., Ecklund, W. L., Johnston, P. E., and Gage, K.: Boundary layer development over a tropical island during the Maritime Continent Thunderstorm Experiment, J. Atmos. Sci., 58, 2163-2179, 2001.

Sui, C. H. and Lau, K. M.: Multiscale phenomena in the tropical atmosphere over the western Pacific, Mon. Wea. Rev., 120, 407430, 1992.

van der Werf, G. R., Randerson, J. T., Giglio, L., Collatz, G. J., Kasibhatla, P. S., and Arellano Jr., A. S.: Interannual variability in global biomass burning emissions from 1997 to 2004, Atmos. Chem. and Phys., 6, 3423-3441, 2006.

van der Werf, G. R., Dempewolf, J., Trigg, S. N., Randerson, J. T., 
Giglio, L., Murdiyarso, D., Peters, W., Morton, D. C., Collatz, G. J., Dolman, A. J., and DeFries, R. S.: Climate regulation of fire emissions and deforestation in equatorial Asia, Proc. Natl. Acad. Sci., 105, 20350-20355, doi:10.1073/pnas.0803375105, 2008.

Williams, M. and Houze, R. A.: Satellite-observed characteristics of winter monsoon cloud clusters, Mon. Weather Rev., 115, 505519, 1987.
Yang, G. Y. and Slingo, J. M.: The diurnal cycle in the tropics, Mon. Weather Rev., 129, 784-801, 2001.

Zhang, C.: Large-scale variability of atmospheric deep convection in relation to sea surface temperature in the tropics, B. Am. Meteorol. Soc., 6, 1898-1913, 1993. 